\title{
Clausewitz and Foucault: war and power
}

\author{
Roger Deacon
}

\begin{abstract}
Carl von Clausewitz's On War has influenced theorists across a wide range of disciplines, and one such was the late French philosopher and historian, Michel Foucault. This paper considers what at first sight appears to be Foucault's reversal of Clausewitz, but which on closer examination can be seen to be an accordance with many striking parallels. It is argued that Foucault's reconceptualisation of modern, or disciplinary, relations of power corresponds remarkably closely with Clausewitz's analysis of war, to the extent that both power and war can be understood in terms of multiple, unstable, interactive and variable relations of force, governed by rationality but often resistant to analysis, the significance of which lies primarily in their fluctuating and reciprocal outcomes and consequences, and not least their moral and psychological components and effects.
\end{abstract}

\section{Introduction}

Shortly after the beginning of the nineteenth century, a soldier who had developed an interest in philosophy bequeathed to history an unfinished and only partly revised study of war. Towards the end of the twentieth century, a philosopher who had developed an interest in war bestowed on the present an equally unfinished study of power. The former, Carl von Clausewitz, a German, devoted the first chapter of his study to a definition of war, deducing, famously, that "War is Merely the Continuation of Policy by Other Means" (Clausewitz 1976: 87). The latter, Michel Foucault, a Frenchman, at the end of a book intended to provide the 'historical background' to a sixvolume study of power, concluded, memorably, that modern disciplinary power can only be understood on the basis of "the necessity of combat and the rules of strategy" (Foucault 1986: 308).

At face value, Clausewitz and Foucault appear to occupy opposite ends of the spectrum when it comes to analysing the relationship between war and politics. Certainly, Foucault made great play of reversing Clausewitz's dictum (Foucault 1986: 168; 1980a: 90; 1982: 222). Yet, contrary to appearances, a closer examination of On War, on the one hand, and of Discipline and Punish and The History of Sexuality, among other texts, on the other hand, reveals that the two theorists are far closer and much more

- Dr Roger Deacon teaches philosophy and theory of education in the School of Education, University of Natal, Durban. He is the Managing Editor of Theoria: A Journal of Social and Political Theory. His most recent publications include "Strategies of Governance: Michel Foucault on Power", Theoria 92 1998, and "Discipline and Homophobia in South African Schools: The Limits of Legislated Transformation" in D. Epstein \& J.T. Sears (eds.), A Dangerous Knowing: Sexuality, Pedagogy and Popular Culture (London: Cassell, 1999), pp. 164-181 (with R. Morrell \& J. Prinsloo). The current foci of his research are the educational implications of postmodernism, the origins of early modern education, and the art and politics of war. 


\section{Deacon}

in accord than might be imagined. Indeed, there are several instances where a Foucauldian reading and internalization of $O n$ War suggests itself, sometimes even down to the choice of words and phrases. This paper explores the proximity of Clausewitz and Foucault, suggesting that, for each, both war and power are complex, multifaceted, variable and relational phenomena, characterised by the constant interaction of a multiplicity of force relations. Despite this inherent uncertainty and instability, both war and power are considered to be governed by rationality, which nevertheless neither mitigates their violence nor annuls their passion. Neither war nor power is reducible to the aims and objectives of states, governments, classes or ideologies, let alone individual politicians or generals, nor do they function in fixed or one-sided ways; instead, their significance lies primarily in their fluctuating and reciprocal outcomes and consequences, not least their moral and psychological components and effects.

\section{2. 'Permanent provocation'}

Clausewitz wishes to keep the plant of his theory of war "close to its proper soil experience" (1976: 61), and to maintain a balance between war's violence, creativity and rationality, "like an object suspended between three magnets" (1976: 89). Foucault is interested in specific contemporary experiences ("like madness, illness, transgression of laws, sexuality [and] self-identity" - Foucault 1981b: 239), in their tripartite relation to knowledge, power and ethics. Both contend that, in politics as in war, pure theory divorced from real experience is much more of a liability than an advantage. Were the interests of two military commanders opposed in equal measure to each other, as they would be in pure theory, Clausewitz notes, "a principle of polarity" would exist between them, and "every advantage gained by one side would be a precisely equal disadvantage to the other" (Clausewitz 1976: 83). In more modern terminology, such a relationship would be called zero-sum, and has been applied to situations as diverse as nuclear firststrike capability and class struggle.

No sooner has Clausewitz mentioned this, however, than he points out that differences in the nature and strength of attacks and defenses, imperfect knowledge of situations, and the element of chance ensure that polarity, or zero-sum, is never achieved. It follows that any theory of war must accept that when "we are dealing with two different things that have a common relation external to themselves, the polarity lies not in the things but in their relationship" (Clausewitz 1976: 83; emphasis in the original). By the same token, for Foucault, victory or defeat in politics "does not obey the law of all or nothing" (Foucault 1986: 27). More importantly, rather than narrowly conceiving of power and resistance as fixed and antithetical nodes, he argues that we must shift our focus to the relations between these two poles: "Power should be studied not on the basis of the primary terms of the power-relation, but on the basis of that relation itself, insofar as it determines the elements on which it bears" (Foucault 1980c: 15; emphasis in the original).

What this joint rejection of the principle of polarity suggests is that neither war nor power is reducible to the aims and objectives of the protagonists. Not discounting the role Clausewitz attributes to military genius (see Book I, Chapter 3), or Foucault to critical inventiveness (1984: 42), there are simply too many factors, both external and 
internal (or, as Clausewitz would say, both objective and subjective) which structure and condition the forces directly involved: the skill, experience, training, discipline and daring of politicians and generals, activists and soldiers; clarity of goals and objectives; the effect of compromise and negotiation; commitment and esprit de corps; numerical, technological or ideological superiority; surprise; speed; planning; timing; intelligence; communications; cunning; the concentration and unification of available force; allies and supporters; fatigue; logistics; terrain and circumstances; weather; passion, luck and chance.

Bonaparte rightly said in this connection that many of the decisions faced by the commander-in-chief resemble mathematical problems worthy of the gifts of a Newton or an Euler (Clausewitz 1976: 112; emphasis in the original; see also 1976: 586).

And even a Bonaparte must contend with another characteristic of political and military activity, namely, "uncertainty of all information": "all action takes place, so to speak, in a kind of twilight, which, like fog or moonlight, often tends to make things seem grotesque and larger than they really are" (Clausewitz 1976: 140). It follows that if one is to think and act, politically or militarily, amidst such an unstable and uncertain swirl of conditioning factors, some of which are advantageous, some contradictory, and many simply undecidable, perhaps the most practicable way forward is to set aside, as far as possible, all those abstract determinants as determinants, and to concentrate instead on the concrete relationships that presently exist or come into being between them.

Most of all, one's calculations must ultimately be grounded on the rather unstable fact that one's opposition, even if firmly on the defensive, is never inactive. (The ability to exercise power through inactivity - or what Bachrach and Baratz (cited in Lukes 1974: 18-19) called nondecision-making - is in itself an action which might be foreseen but which cannot be predicted.) "War", asserts Clausewitz, is "an act of mutual destruction":

Like two incompatible elements, armies must continually destroy one another. Like fire and water they never find themselves in a state of equilibrium but must keep on interacting until one of them has completely disappeared (Clausewitz 1976: 216).

In a like manner, Foucault conceives of power relations as a continuous confrontation of strategies, "a perpetual battle rather than a contract regulating a transaction or a conquest of a territory" (Foucault 1986: 26), or, using a term which has recently become current, as an "agonism": a combat, a competition or "a relationship which is at the same time reciprocal incitation and struggle; less of a face-to-face confrontation which paralyzes both sides than a permanent provocation" (Foucault 1982: 222; Gray 1995: 68).

In this world of war, there is no ultimately sovereign power which might be called upon to end or prevent conflict, nor are there any written or unwritten moral rules capable in the last instance of neutrally arbitrating between antagonists. From Foucault's perspective, this "total war" does not exhaust itself in its contradictions, renounce violence and end by submitting to civil laws: 
On the contrary, the law is a calculated and relentless pleasure, delight in the promised blood, which permits the perpetual instigation of new dominations and the staging of meticulously repeated scenes of violence (Foucault 1977: 151).

This is not to say that anything goes in this world of war, or that there are no rules; rather, the rules themselves are forged in combat and, like a blacksmith's creations, may prove to be well-tempered and long-lasting or brittle and short-lived (Deacon 1998: 137). And, "if it is all a calculation of probabilities based on given individuals and conditions", then the "essential factor in the equation" becomes "the political object" (Clausewitz 1976: 80; emphasis in the original). In addition, "concern, prudence, and fear of excessive risks" (Clausewitz 1976: 218) often act to rationalise and tame what would otherwise always be an unrestrained guerre à outrance.

War and politics may be governed by rationality, but this does not mean either that war is dispassionate, or that its violence is somehow anachronistic; on the contrary, war is "an act of force, and there is no logical limit to the application of that force" (Clausewitz 1976: 77) which consequently tends towards slaughter, and "[b]etween violence and rationality there is no incompatibility (Foucault 1980d: 4). With respect to the first point, "it would an obvious fallacy to imagine war between civilized peoples as resulting merely from a rational act on the part of their governments and to conceive of war as gradually ridding itself of passion" (Clausewitz 1976: 76). Secondly, "[h] umanity does not gradually progress from combat to combat until it arrives at universal reciprocity, where the rule of law finally replaces warfare; humanity installs each of its violences in a system of rules and thus proceeds from domination to domination" (Foucault 1977: 151).

The rationalised violence of modern relations of power is a testament not to their growing civility and humanitarianism but to their greater efficiency and economy. "If ... civilized nations do not put their prisoners to death or devastate cities and countries, it is because intelligence plays a larger part in their methods of warfare and has taught them more effective ways of using force than the crude expression of instinct" (Clausewitz 1976: 76). Foucault takes this further by insisting that what Clausewitz here refers to as 'intelligence' is an aspect of the modern power over life (or bio-power), aimed at ensuring, sustaining, administering and multiplying the lives of rational subjects. Using the example of the justice system, he argues that it is "the return effects of punishment" in the form of the pain and guilt felt by the punishing authority (Foucault 1986: 91), and not humanitarian feelings, or "the economy of power that they [judges] exercise, and not that of their scruples or their humanism, that makes them pass 'therapeutic' sentences and recommend 'rehabilitating' periods of imprisonment" (Foucault 1986: 304; 1981a: 138).

Despite the ceaseless conflict that marks both war and power, intervals - usually temporary, always strategic - when all is quiet at the front are far from unusual. Quite the contrary, in fact: "immobility and inactivity are the normal state of armies in war, and action is the exception" (Clausewitz 1976: 217; emphasis in the original). For Foucault, too, power relations constantly fluctuate between open confrontations marked by "the free play of antagonistic reactions" between governors and governed, and periods of relative stability in which the conduct of erstwhile adversaries can be governed "in a fairly constant manner and with reasonable certainty" (Foucault 1982: 225). Those occasions when "[w] ar often is nothing more than armed neutrality, a threatening attitude 
meant to support negotiations" (Clausewitz 1976: 218), correspond to the latter. A proliferation of struggles does not mean that power relations are inactive, have ceased to exist or are being worsted, but through their existence and prosecution constitute among the most essential components of power. Likewise, long periods of stable government underpinned by widespread consent do not indicate the taming of power relations, but only a contingently successful strategy. In this sense, Foucault's strategies of power are much like Clausewitz's strategies of war, always potentially unstable: at best, they equilibrate, though usually temporarily; at worst, as we shall see, they evolve into what Foucault calls 'states of domination'.

For Clausewitz, despite the fact that

general conditions of inactivity ... [are] so characteristic of many wars [,] ... the possibility of a battle always remains a focus for both sides, a distant aim towards which their courses of action can be directed (1976: 259);

while for Foucault, "[e]very power relationship implies, at least in potentia, a strategy of struggle" or confrontation (Foucault 1982: 225). Thus, for both theorists, action and reaction are a focal point of their respective analyses of war and power. Clausewitz elaborates: "[w]ar ... is not the action of a living force upon a lifeless mass (total nonresistance would be no war at all) but always the collision of two living forces" (Clausewitz 1976: 77). There is a clear correspondence here with the distinction that Foucault makes between 'states of domination' and relations of power. The former (which political philosophers since Hobbes have commonly taken to exhaust the concept of power) tend to be "firmly set and congealed", occurring when an individual or group 'blocks a field of relations of power', "renders them impassive and invariable" and prevents "all reversibility of movement" (Foucault 1987: 114). Where possibilities for resistance, reversal or compromise do not exist, "there is no relationship of power; slavery is not a power relationship when man is in chains" (Foucault 1982: 221); or, in other words, "a man who is chained up and beaten is subject to force being exerted over him. Not power" (Foucault 1981b: 253). To understand power only as a state of domination, then, is comparable to treating war as a unilateral action directed against an unresisting 'lifeless mass'.

Relations of power, on the other hand (or what Foucault also called "strategic games between liberties" - 1987: 130), are "variable", "changeable, reversible and unstable" (Foucault 1987: 114,123); they are "exercised only over free subjects, and only insofar as they are free" (Foucault 1982: 221), and they both depend upon the recognition of "'the other' (the one over whom power is exercised) ... as a person who acts", making possible "a whole field of responses, reactions, results, and possible inventions" (Foucault 1982: 220; see also Deleuze 1988: 70). "In war," writes Clausewitz, "the will is directed at an animate object that reacts" (1976: 149; emphasis in the original). "A relationship of power", argues Foucault, "is ... a mode of action which does not act directly and immediately on others. Instead it acts upon their actions" (Foucault 1982: 220). Here again the military clash of arms and the political pulse of power coincide: a 'collision of living forces', consisting of diverse groups and individuals, at various levels of authority, with different degrees of influence, and with varying intentions and skills, assessing probabilities and acting and reacting strategically and tactically on the basis of limited information and in terms of the circumstances and conditions at hand. 
Part of the originality of On War was its refusal, for the most part, to posit principles of war, and its rejection of earlier attempts to ground a theory of war upon one or other primary factor, such as 'numerical superiority', 'supply', 'base' or 'interior lines'. Against such theories, Clausewitz commented:

They aim at fixed values; but in war everything is uncertain, and calculations have to be made with variable quantities. They direct the inquiry exclusively toward physical quantities, whereas all military action is intertwined with psychological forces and effects. They consider only unilateral action, whereas war consists of a continuous interaction of opposites (Clausewitz 1976: 136).

Foucault raised similar concerns in his critique of what he referred to as the "juridico-discursive" emphasis in conventional political thought, which is fixated upon the state and its laws and apparatuses, and premised on self-conscious sovereign actors possessing and exercising power intentionally and comprehensively in a one-sided, topdown and dominating fashion over comparatively powerless others (Foucault 1981a: 825; 1980a: 139-40; 1980b: 15; 1986: 27-8). Relations of power, for Foucault, in many instances "don't pass directly via the State apparatus, yet often sustain the State more effectively than its own institutions, enlarging and maximising its effectiveness" (Foucault 1980a: 72-3); and their functioning is much more complex than assumed (Foucault 1980a: 188).

An important strategic injunction flows from this, for both politics and war: not only is the state, in politics, not "absolutely essential as a target to be attacked and a privileged position to be taken over" (Foucault 1979: 20), but, in war, the capture of a capital city, or of a certain territory, is in itself often only of secondary importance in relation to the destruction of the enemy's means and will to resist (Clausewitz 1976: 228). Unless we learn to regard war

as a chain of linked engagements each leading to the next, ... [we are likely to] instead succumb to the idea that the capture of certain geographical points or the seizure of undefended provinces are of value in themselves, ... [and may] also ignore the possibility that their possession may later lead to definite disadvantages (Clausewitz 1976: 182; emphasis in the original).

Moreover, for Foucault, physical institutions are only forms in which relations of power (and forms of knowledge) materialise, and greater attention should be paid to factors such as traditional predispositions, legal structures, customs and fashions (as in families), regulations and hierarchies (as in schools and military institutions), and functions of general surveillance (via the state) (Foucault 1982: 223; 1989: 188). Finally, power relations, though often unequal, are never one-sided: "There is no power without potential refusal or revolt" (Foucault 1981b: 253).

\section{3. 'A duel on a larger scale'}

The constant interaction that characterises both war and power ensures that actions and events are never isolated but always influenced by others, which in turn means that success never consists of a single decisive blow, all resources can never be brought to bear simultaneously, and the outcome is never final (Clausewitz 1976: 78-9). 
Each side ... compels its opponent to follow suit; a reciprocal action is started which must lead, in theory, to extremes. ... So long as I have not overthrown my opponent I am bound to fear he may overthrow me. Thus I am not in control: he dictates to me as much as I dictate to him (Clausewitz 1976: 77).

The open, uncertain and dyadic nature of politics and war gives them a game-like quality, "a game of cards" or "a duel on a larger scale" for Clausewitz (1976: 86, 75), "strategic games" for Foucault (1987: 129; 1988: 168); nevertheless, "war is no pastime" (Clausewitz 1976: 86). If Foucault paid only the briefest attention to On War, it was most certainly to the very first page where war is likened to a contest between "a pair of wrestlers. Each tries through physical force to compel the other to do his will; his immediate aim is to throw his opponent in order to make him incapable of further resistance" (Clausewitz 1976: 75; emphasis in the original). Foucault's discussion of the meaning of the term 'strategy' (as means to an end, as game-plan, and as means destined to win a struggle) maps almost directly onto Clausewitz here: all three meanings, argued Foucault, "come together in situations of confrontation - war or games - where the objective is to act upon an adversary in such a manner as to render the struggle impossible for him" (Foucault 1982: 225).

Another consequence of understanding war and power as processes of continuous interaction is a rethinking of both action and reaction. Clausewitz is unique amongst military theorists in the attention he devoted to what he called 'friction', wherein the simplest things - "countless minor incidents" (1976: 119), including danger, fatigue, privation, ill-discipline, intelligence (or lack thereof) and weather - can complicate and wear down the war machine, preventing it from achieving optimum performance. Most importantly, the effect of friction is such that "[a]ction in war is like movement in a resistant element" (Clausewitz 1976: 120). Friction, in this sense, is not something which acts upon strategy from the outside, something which could be avoided; it is intertwined with strategy and, indeed, its essential support, as in Clausewitz's example of the relation of water to the swimmer.

Foucault also took pains to insist that 'resistance' is not something externally opposed to power as a centralised, homogenous locus but is an 'energy' built into power as a dispersed and unstable set of relations:

Where there is power, there is resistance, and yet, or rather consequently, this resistance is never in a position of exteriority in relation to power (Foucault 1981a: 95).

Resistance or defense is not merely reactive, ultimately passive, and "doomed to perpetual defeat" (Foucault 1981a: 96); attack and defense, action and reaction are bound together as elements of "a contest with more than one round" (Foucault 1970: 385). In Clausewitz's terms, "resistance is a form of action, aimed at destroying enough of the enemy's power to force him to renounce his intentions" (Clausewitz 1976: 93); to which Foucault - in a Gandhian moment - might well have added: "It is up to us to defend ourselves so well that the institutions will be forced to reform themselves" (Foucault, in Macey 1993: 418, 438).

Furthermore, since a defender often has an advantage in the choice of terrain, the theatre of operations, and the support of the population, "defense is a stronger form of 
fighting than attack" (Clausewitz 1976: 84). Nevertheless, defense is not separate in kind from attack: a "sudden powerful transition to the offensive - the flashing sword of vengeance" must be "in the commander's mind from the start, ... an integral part of his idea of defense" (Clausewitz 1976: 370). "Even in offensive warfare in the open field the great secret consists in defensive combats, and in obliging the enemy to attack" (Napoleon, in Chandler 1987: 60). Ultimately, the best defenses, the most flexible and adventitious deployments of forces, are premised on the possibility of counterattack: built into every power relationship is the potential for inequalities to be reversed, for the antagonists to constitute, each for the other, "a kind of permanent limit, a point of possible reversal" (Foucault 1982: 225). "Pure defense ... would be completely contrary to the idea of war, since it would mean that only one side was waging it"; hence, "if we are really waging war, we must return the enemy's blows"; therefore, "the defensive form of war is not a simple shield, but a shield made up of well-directed blows" (Clausewitz 1976: 357). Attack and defense, or power and resistance, are characteristic of all sides in all struggles: both are utilised by superior and subordinate alike and are thus often indistinguishable. As Alcibiades put it to the Athenians on the occasion of the expedition to Sicily during the Peloponnesian War, "[o]ne does not only defend oneself against a superior power when one is attacked; one takes measures in advance to prevent the attack from materializing" (Thucydides 1971: 379)

Both Clausewitz and Foucault take this interchangeability of attack and defense even further, however, along with all the implications for moral judgements about which side is to be deemed the aggressor.

War serves the purpose of the defense more than that of the aggressor. It is only aggression that calls forth defense, and war along with it. The aggressor is always peace-loving (as Bonaparte always claimed to be); he would prefer to take over our country unopposed. To prevent his doing so one must be willing to make war and be prepared for it. In other words it is the weak, those likely to need defense, who should always be armed in order not to be overwhelmed (Clausewitz 1976: 370).

Notwithstanding the tongue-in-cheek reference to the peace-loving aggressor, it is clear that Clausewitz was convinced of the necessity for all states to prepare themselves against possible future attacks. This idea that the weak, in seeking to secure their own protection, may inadvertently bring upon themselves precisely the attack, by an equally anxious neighbour, which they originally feared, is common enough in modern political and military analysis. What is less often remarked upon is the Nietzschean nature of this argument, such that the weak are partly responsible for calling the strong into being, and hence for their own potential victimisation; and here Foucault's own theoretical roots align him once again with Clausewitz, when he notes that in the dyadic interrelationship between power and resistance, existing inequalities are "sometimes extended by the position of those who are dominated" (Foucault 1986: 27).

Forever clasped in a hostile embrace, it follows from the strategic danse macabre sketched out above that the political and military options available to antagonists are seldom simple or transparent, but could unwittingly strengthen instead of weaken an adversary, or, instead of warding off an opponent, bring it even more quickly into play. The Allied demand for the unconditional surrender of Axis forces during World War II, an act of power made ironically at the moment of their greatest weakness, provides an 
example of such unintended or unexpected consequences. On the one hand, the demand, in the context of subsequent Allied victories, weakened the resolve of a failing Italy which entered into secret negotiations for an armistice, and the collapse of Italy in turn hastened the end of the war in Europe and forced Germany to sue for peace in May 1945. On the other hand, the demand stiffened Japanese resistance and kamikaze attacks in the Pacific, which in turn were used to justify the dropping of atomic bombs on Hiroshima and Nagasaki. Even when clearly antagonistic strategies collide the outcome is seldom preordained: the transformation of the clash between apartheid and anti-apartheid forces into an extraordinarily peacefully negotiated settlement is a case in point (Deacon 1998: 135).

Regardless whether strategy is offensive or defensive, intended or unintended, active or reactive, neither the labour of war nor the exercise of power can be reduced to physical violence or repression. Napoleon contended that "[i]n war the moral is to the physical force as three to one" (quoted in Napier 1851: 89). Elaborates Clausewitz: "One might say that the physical [factors] seem little more than the wooden hilt, while the moral factors are the precious metal, the real weapon, the finely-honed blade" (Clausewitz 1976: 185). In the same vein, Foucault argued that power relations do not merely distort truth or repress people:

What makes power hold good, what makes it accepted, is simply the fact that it doesn't only weigh on us as a force that says no, but that it traverses and produces things, it induces pleasure, forms knowledge, produces discourse (Foucault 1980a: 119).

Spurred on by the productivity of 'permanent provocation' that typifies both power and war, mechanisms of combat are enhanced ("the 'production' of destruction, as with the army" - Foucault 1980a: 161; 1986: 219) and new forms of knowledge crystallize, to the extent that the development of parts of modern science, both human and natural, have been directly premised on the requirements of the military: the military camp which organised space in order to facilitate observation provided a model for many panoptic technologies (Foucault 1986: 171; Smart 1985: 86); and the discipline of engineering emerged out of techniques of fortification construction and siege warfare, with which mathematics was also closely associated (Ariès 1962: 197-199).

In fact, war on its own is less about naked coercion than is commonly assumed. Moral and psychological factors - which include "the spirit and other moral qualities of an army, a general or a government, the temper of the population of the theatre of war [not to mention the home or domestic theatre], the moral effects of victory or defeat" "constitute the spirit that permeates war as a whole" (Clausewitz 1976: 184), and "exert a decisive influence on the elements involved in war" (Clausewitz 1976: 127). Besides, not only is it "a crude error to equate attack with the idea of assault alone" (Clausewitz 1976: 370 ), but "[m]ilitary activity is never directed against material force alone; it is always aimed simultaneously at the moral forces which give it life, and the two cannot be separated" (Clausewitz 1976: 137). Suitable moral training can be indispensable for battlefield success, which in turn is essential for the manufacture of certain moral forces: on the one hand, that most fearsome of military tactics, the cavalry or bayonet charge, depended on the psychological preparedness and discipline of the attackers, and was commonly preceded by a hearty cheer intended to embolden and impel them (Nosworthy 


\section{Deacon}

1995: 241; see also Weber 1970: 265-57); on the other hand, only "a series of victorious wars" or "frequent exertions of the army to the utmost limits of its strength" can produce esprit de corps (Clausewitz 1976: 187-9).

\section{Conclusion}

Both war and politics, it has been argued, are characterised by "the use of force under conditions of danger, subject to constant interaction with an adversary, [as well as] ... the efforts of spirit and courage to achieve a desired end" (Clausewitz 1976: 133). However, neither Clausewitz nor Foucault wished to suggest that war and politics are indistinguishable. The political character of war, and the military character of power, are aids to understanding and analysis, not absolute truths; they are to be tested and applied in real situations, not taken at their theoretical face value.

War is not like a field of wheat, which, without regard to the individual stalk, may be mown more or less efficiently depending on the quality of the scythe; it is like a stand of mature trees in which the axe has to be used judiciously according to the characteristics and development of each individual trunk (Clausewitz 1976: 153).

"[T]he less intense the motives," remarked Clausewitz, "war ... will seem increasingly political in character" (1976: 88; emphasis in the original), and, by analogy, politics will seem increasingly military in character. Consider the weak military (but strong political) motivations for United States involvement in Korea and Vietnam; consider also the Cold War political climate which made McCarthyism and Kent State University possible. By contrast, the Gulf War had a strong military motivation - the protection of oil assets - yet in this instance the world's undisputed military superpower felt it necessary to channel its demands through the political machinery of the United Nations.

In hypothesising "that power is war, a war continued by other means" (Foucault 1980a: 90), Foucault makes clear that he seeks not to deny but to expand Clausewitz's relevance:

It may be that war as strategy is a continuation of politics. But it must not be forgotten that 'politics' has been conceived as a continuation, if not exactly and directly of war, at least of the military model as a fundamental means of preventing civil disorder. Politics, as a technique of internal peace and order, sought to implement the mechanism of the perfect army .... It is strategy that makes it possible to understand warfare as a way of conducting politics between states; it is tactics that makes it possible to understand the army as a principle for maintaining the absence of warfare in civil society (Foucault 1986: 168).

Clausewitz and Foucault are far from being incompatible: at the level of strategy, war is no doubt a continuation of politics by other means; at the level of tactics, politics is a continuation of war by other means. Though not the same, the two levels overlap. Both the philosopher of war and the strategist of philosophy arrive on the same battlefield, albeit by different routes of march, and in command of a different mixture of regular and irregular troops. While they dream of the complete annihilation of the enemy, their scouts have been unable to determine the precise size, location and quality 
of the enemy's forces. Even the terrain and the weather submit merely to probabilistic calculations; the morale and fitness of some of their levies have yet to be tested; and the enemy, even when occupying fixed defenses, is nevertheless continuously reacting to their movements, and initiating actions on its own accord, by bringing up reserves or withdrawing portions of its forces. Hence they decide, for the time being, to skirt what appears to be a well-defended citadel at the centre of the enemy formation. Instead, they send mobile forces against the enemy's flanks and lines of communication and supply, hoping to unnerve their opponent and gain a psychological advantage. Fully aware that every defense is premised on attack, they successfully beat off an enemy attack on one part of the battlefield, and follow it up with a vigorous and violent counter attack, all the while passionately exhorting their troops to even greater feats. Regardless of whether they win or lose this day's fighting, they will prepare themselves for the battles that tomorrow will inevitably bring, in these serious and unending games of politics and war.

\section{References}

Ariès,P. 1962 Centuries of Childhood (London, Jonathan Cape)

Chandler,D.G. 1987 The Military Maxims of Napoleon Transl.G.C.D'Aguilar, intro. D.G.Chandler (London, Greenhill Books)

Clausewitz,C.von 1976 On War Ed. and transl. M.Howard and P.Paret (Princeton, Princeton University Press)

Deacon,R. 1998 "Strategies of Governance: Michel Foucault on Power" Theoria 92, 1998 113-148

Deleuze,G. 1988 Foucault (Minneapolis, University of Minnesota Press)

Foucault,M. 1970 The Order of Things: An Archaeology of the Human Sciences

(London, Tavistock)

Foucault,M. 1977 Language, Counter-Memory, Practice: Selected Essays and Interviews Ed. D.F.Bouchard (Oxford, Blackwell)

Foucault,M. 1979 “Governmentality” Ideology and Consciousness 6 5-21

Foucault,M. 1980a Power/Knowledge: Selected Interviews and Other Writings 19721977 Ed. C.Gordon (New York, Pantheon)

Foucault,M. 1980b Herculine Barbin: Being the Recently Discovered Memoirs of a Nineteenth-Century French Hermaphrodite (Brighton, Harvester)

Foucault,M. 1980c "War in the Filigree of Peace: Course Summary" Oxford Literary Review 4,2 15-19

Foucault,M. 1980d "M.Dillon: Conversation with Michel Foucault" The Threepenny Review 1,1 4-5

Foucault,M. 1981a The History of Sexuality: An Introduction (Harmondsworth, Penguin) Foucault,M. 1981b "Omnes et Singulatim: Towards a Criticism of 'Political Reason" in S.M.McMurrin (ed) The Tanner Lectures on Human Values II (Cambridge, Cambridge University Press) 223-254

Foucault,M. 1982 "The Subject and Power", Afterword to H.L.Dreyfus \& P.Rabinow Michel Foucault: Beyond Structuralism and Hermeneutics (Brighton, Harvester) Foucault,M. 1984 The Foucault Reader Ed. P.Rabinow (Harmondsworth, Penguin) 
Foucault,M. 1986 Discipline and Punish: The Birth of the Prison (Harmondsworth, Peregrine)

Foucault,M. 1987 "The Ethic of Care for the Self as a Practice of Freedom - An Interview with Michel Foucault" Philosophy and Social Criticism 12, 2/3 112-131

Foucault,M. 1988 Michel Foucault: Politics, Philosophy, Culture. Interviews and Other Writings 1977-1984 Ed. L.Kritzman (London, Routledge)

Foucault,M. 1989 Foucault Live (Interviews 1966-84) Ed. S.Lotringer (New York, Semiotexte)

Gray,J. 1995 Enlightenment's Wake: Politics and Culture at the close of the Modern Age (London, Routledge)

Lukes,S. 1974 Power: A Radical View (London, Macmillan)

Macey,D. 1993 The Lives of Michel Foucault (London, Hutchinson)

Napier,W. 1851 History of the War in the Peninsula and in the South of France from the Year 1807 to the Year 1814 vol.1 (London, Frederick Warne \& Co.)

Nosworthy,B. 1995 Battle Tactics of Napoleon and his Enemies (London, Constable)

Smart,B. 1985 Michel Foucault (London, Routledge)

Thucydides 1971 The Peloponnesian War (Harmondsworth, Penguin)

Weber,M. 1970 From Max Weber: Essays in Sociology Ed. and transl. H.Gerth \& C.Wright Mills (London, Routledge and Kegan Paul) 